\title{
Lead isotopic compositions in the EPICA Dome C ice core and Southern Hemisphere Potential Source Areas ${ }^{\text {is }}$
}

\author{
P. Vallelonga ${ }^{\mathrm{a}, \mathrm{b}, *}$, P. Gabrielli ${ }^{\mathrm{c}}$, E. Balliana ${ }^{\mathrm{d}, \mathrm{e}}, \mathrm{A}$. Wegner ${ }^{\mathrm{f}}$, B. Delmonte ${ }^{\mathrm{g}}$, C. Turetta $^{\mathrm{a}}$, G. Burton $^{\mathrm{b}}$, \\ F. Vanhaecke ${ }^{\text {d, K.J.R. Rosman }}{ }^{\text {b, }}$, S. Hong ${ }^{\text {h }}$, C.F. Boutron ${ }^{\mathrm{i}, \mathrm{j}}$, P. Cescon ${ }^{\mathrm{a}, \mathrm{e}}$, C. Barbante ${ }^{\mathrm{a}, \mathrm{e}}$ \\ a Institute for the Dynamics of Environmental Processes - CNR, Calle Larga Santa Marta 2137, I-30123 Venice, Italy \\ ${ }^{\mathrm{b}}$ Department of Imaging and Applied Physics, Curtin University of Technology, GPO Box U1987, Perth, WA 6845, Australia \\ ' School of Earth Sciences and Byrd Polar Research Center, The Ohio State University, 108 Scott Hall, 1090 Carmack Road, Columbus, OH 43210-1002, USA \\ ${ }^{\mathrm{d}}$ Department of Analytical Chemistry, Ghent University, Krijgslaan 281-S12, B-9000 Ghent, Belgium \\ ${ }^{\mathrm{e}}$ Department of Environmental Sciences, University of Venice Ca' Foscari, Calle Larga Santa Marta 2137, I-30123 Venice, Italy \\ ${ }^{\mathrm{f}}$ Alfred-Wegener-Institut, Am Alten Hafen 26, D-27568 Bremerhaven, Germany \\ ${ }^{\mathrm{g}}$ Dipartimento di Scienze dell'Ambiente e del Territorio, Universitá degli Studi di Milano-Bicocca, Piazza della Scienza 1, 20126, Milan, Italy \\ ${ }^{\mathrm{h}}$ Korea Polar Research Institute (KOPRI), 806 Get-Pearl Tower, Songdo Technopark, 7-50 Songdo-dong, Yunsu-ku, Incheon, 406-840, Korea \\ ${ }^{\mathrm{i}}$ Laboratoire de Glaciologie et Géophysique de l'Environnement du C.N.R.S., 54 rue Molière - Domaine Universitaire - BP 96 - 38402 St Martin d'Hères Cedex, France \\ ${ }^{\mathrm{j}}$ Université Joseph Fourier de Grenoble (Institut Universitaire de France), B.P. 68, 38041 Grenoble, France
}

\section{A R T I C L E I N F O}

\section{Article history:}

Received 19 December 2008

Received in revised form

24 June 2009

Accepted 25 June 2009

\begin{abstract}
A B S T R A C T
A record of $\mathrm{Pb}$ isotopic compositions and $\mathrm{Pb}$ and $\mathrm{Ba}$ concentrations are presented for the EPICA Dome $\mathrm{C}$ ice core covering the past $220 \mathrm{ky}$, indicating the characteristics of dust and volcanic $\mathrm{Pb}$ deposition in central East Antarctica. Lead isotopic compositions are also reported in a suite of soil and loess samples from the Southern Hemisphere (Australia, Southern Africa, Southern South America, New Zealand, Antarctica) in order to evaluate the provenance of dust present in Antarctic ice. Lead isotopic compositions in Dome C ice support the contention that Southern South America was an important source of dust in Antarctica during the last two glacial maxima, and furthermore suggest occasional dust contributions from local Antarctic sources. The isotopic signature of $\mathrm{Pb}$ in Antarctic ice is altered by the presence of volcanic $\mathrm{Pb}$, inhibiting the evaluation of glacial-interglacial changes in dust sources and the evaluation of Australia as a source of dust to Antarctica. Consequently, an accurate evaluation of the predominant source(s) of Antarctic dust can only be obtained from glacial maxima, when dust-Pb concentrations were greatest. These data confirm that volcanic $\mathrm{Pb}$ is present throughout Antarctica and is emitted in a physical phase that is free from $\mathrm{Ba}$, while dust $\mathrm{Pb}$ is transported within a matrix containing Ba and other crustal elements.
\end{abstract}

\footnotetext{
is This paper is dedicated to the memory of our friend and colleague Professor Kevin J.R. Rosman who, among other achievements, pioneered the accurate determination of lead isotopic compositions in polar snow and ice.

* Corresponding author. Tel.: +39041 2348504; fax: +390412348628.

E-mail addresses: vallelonga@unive.it (P. Vallelonga), gabrielli.1@osu.edu (P. Gabrielli), eleonora.balliana@ugent.be (E. Balliana), anna.wegner@awi.de (A. Wegner), barbara.delmonte@unimib.it (B. Delmonte), clara.turetta@idpa.cnr.it (C. Turetta), g.burton@curtin.edu.au (G. Burton), frank.vanhaecke@ugent.be (F. Vanhaecke), smhong@kopri.re.kr (S. Hong), boutron@lgge.obs.ujf-grenoble.fr (C.F. Boutron), cescon@unive.it (P. Cescon), barbante@unive.it (C. Barbante).

1 Deceased.
}

\section{Introduction}

Dust is an active component of the Earth's climate system, both contributing to and responding to changes in radiative forcing and ocean biogeochemistry (Mahowald et al., 2005). The polar ice sheets are an ideal archive for monitoring variations in dust fluxes and other climate parameters, and have been crucial to understanding the role of dust in climate variability (Fischer et al., 2007). It has recently been suggested that variations in Antarctic dust fluxes are primarily driven by strengthened Aeolian deflation in source regions and weakening of the hydrological cycle rather than variations in atmospheric transport parameters or moderations in meridional transport (Lambert et al., 2008). 
Grousset and co-workers have demonstrated the utility and selectivity of $\mathrm{Sr}$ and $\mathrm{Nd}$ isotopic systems for investigation of dust provenance in ice cores (Grousset and Biscaye, 2005). Initial studies required kg-size samples, limiting analytical resolution and sample availability to a few glacial samples, but ongoing development of the analytical technique has seen improvements in sample resolution and recently low-concentration interglacial samples have been analysed (Delmonte et al., 2007).

In parallel, the isotopic signature of dust from Potential Source Areas (PSAs) has been documented. The recent work of Gaiero (2007) reported Sr and Nd isotopic composition for PSA in Southern South America (SSA) indicating the importance of considering high-latitude areas such as Patagonia as well as low-latitude sources located at high altitude such as the Puna-Altiplano plateau in the Andean Cordillera. Revel-Rolland et al. (2006) reported an extensive data set of $\mathrm{Sr}$ and $\mathrm{Nd}$ isotopic signatures in East Australian PSA samples, suggesting the presence of a non-trivial Australian dust contribution to Antarctica during interglacial climate phases. They suggested a 10-20\% Australian dust contribution during glacial phases and up to $50 \%$ during interglacial phases. The changing proportions of dust sources was attributed to changes in primary production of dust in SSA during glacial climate phases resulting from glacial and periglacial processes related to the growth and recession cycles of the Patagonian ice cap.

The use of $\mathrm{Pb}$ isotopes for dust provenance has been limited on account of the extreme contamination controls required to accurately determine $\mathrm{Pb}$ isotopic ratios in pg-level quantities, as well as a dearth of $\mathrm{Pb}$ isotope data for PSAs. Initial studies of $\mathrm{Pb}$ isotopes in Antarctic ice (Rosman et al., 1994) and seawater (Flegal et al., 1993) reported the extent and origins of industrial pollution in the Antarctic environment. Vallelonga et al. (2002a,b) demonstrated that industrial $\mathrm{Pb}$ emissions were efficiently transported to Antarctica from Australia from 1880 AD on, with the influence of leaded gasoline emissions from South America evident since the 1960s. This work demonstrated the efficacy of fine particle transport mechanisms from Australia to coastal Antarctica, and established the extremely low concentrations of $\mathrm{Pb}$ present in Antarctic ice during the Holocene of $\sim 0.3 \mathrm{pg} / \mathrm{g}\left(0.3 \times 10^{-12} \mathrm{~g} / \mathrm{g}\right)$.

Determination of the provenance of Antarctic dust using $\mathrm{Pb}$ isotopes has been hampered by the presence of volcanic $\mathrm{Pb}$ in Antarctica, which has a different isotopic composition to that of dust Pb. Matsumoto and Hinkley (2001) demonstrated the overwhelming presence of highly radiogenic volcanic $\mathrm{Pb}$ in the Taylor Dome ice core, located west of the Transantarctic mountains, with volcanic sources accounting for $\sim 60 \%$ of total $\mathrm{Pb}$ in Taylor Dome ice during the glacial phases and $\sim 95 \%$ during the Holocene. Determinations of volcanic $\mathrm{Pb}$ inputs are usually based on $\mathrm{Pb} / \mathrm{Ba}$ or $\mathrm{Pb} / \mathrm{Al}$ ratios measured in ice samples, with $\mathrm{Ba}$ or $\mathrm{Al}$ used as a continental dust proxy, and the dust-Pb contribution calculated using an estimate of the ratios of the elements in the upper continental crust (e.g. Wedepohl, 1995). Data from other locations in Antarctica indicate comparable or lower volcanic $\mathrm{Pb}$ contributions during the Holocene: $80-90 \%$ volcanic Pb contributions to Law Dome (Vallelonga et al., 2002a,b) and Victoria Land (Van de Velde et al., 2005), $30-80 \%$ volcanic $\mathrm{Pb}$ contributions to Coats Land (Planchon et al., 2003), 20\% volcanic $\mathrm{Pb}$ contributions to Vostok (Hong et al., 2003) and $\sim 15 \%$ volcanic Pb contributions to Dome C (Vallelonga et al., 2005). Hinkley (2007) demonstrated that these volcanic Pb contributions converge on a radiogenic $\mathrm{Pb}$ isotopic composition of ${ }^{206} \mathrm{~Pb} /{ }^{207} \mathrm{~Pb} \sim 1.26$, which corresponds to the $\mathrm{Pb}$ isotopic signatures of ocean island volcanoes as well as Antarctic volcanic provinces, including Mount Erebus.

The availability of data for PSAs has been another limitation to dust provenance studies using $\mathrm{Pb}$ isotopes. Lead isotopic compositions have been reported for South Atlantic and South Pacific
Ocean pelagic sediments (Chow and Patterson, 1962) but no landbased loess or soil data were available before this study. Geochronological studies of volcanic provinces of Antarctica [Erebus: Sun and Hanson (1975), Sims et al. (2008); Marie Byrd Land: Hart et al. (1997); Antarctic Peninsula: Hole et al. (1993)] and the South Sandwich Islands (Barreiro, 1983) ensure that the volcanic $\mathrm{Pb}$ component is already well defined. These studies support the radiogenic signature of Antarctic volcanic emissions indicated by Vallelonga et al. (2002a,b) and Hinkley (2007). Rosman et al. (1998) also identified rocks from a Th-rich province in Enderby Land with matching $\mathrm{Pb}$ isotopic compositions in Law Dome ice.

Recent analysis of $\mathrm{Sr}$ and $\mathrm{Nd}$ isotopic compositions in targeted locations of Southern South America and Australia have greatly stimulated the interpretation of Antarctic ice core data. This work seeks to provide a similar stimulus for the analysis of Antarctic $\mathrm{Pb}$ isotope compositions, by presenting $\mathrm{Pb}$ isotopic compositions in a set of targeted Australian soil and loess samples in arid locations of identified dust production and prolonged aridity during the Quaternary. Furthermore, $\mathrm{Pb}$ isotopes are reported for selected samples previously analysed for $\mathrm{Sr}$ and $\mathrm{Nd}$ by Delmonte et al. (2004) for comparison with existing proxies of PSAs, such as pelagic sediments and volcanic lavas. New data from the EPICA Dome $\mathrm{C}$ ice core are also presented, to improve the statistical reliability of dust provenance evaluations. This work contributes to evaluations of the provenance of Antarctic aerosol, distinguishing between dust and volcanic contributions, and provides an important data set for interpretation of $\mathrm{Pb}$ isotopes in Antarctic ice and snow in future studies.

\section{Regional setting}

\subsection{Ice core samples}

All ice core samples presented here are from the EPICA Dome C (hereafter EDC) core drilled between 1996 and 2005. The location and site characteristics of EDC have already been extensively described (EPICA community members, 2004). Sample dating was assigned using the EDC3 chronology of Parrenin et al. (2007) with paleotemperature information provided by the high-resolution record of deuterium/hydrogen ratios (represented here as $\delta \mathrm{D}$ ) reported by Jouzel et al. (2007). A preliminary data set of 30 EDC samples (Vallelonga et al., 2005) has here been extended to 74 samples covering the period 2-217 kyr BP(86.6-2193.4 m depth). Some of the EDC samples previously reported have also been remeasured to improve the precision of the $\mathrm{Pb}$ isotopic compositions (sample depths: $229.1 \mathrm{~m}$, 432.6 m, 489.0 m, $598.1 \mathrm{~m}, 709.0$ m, $1093.1 \mathrm{~m}, 1643.1 \mathrm{~m}, 2094.4 \mathrm{~m}$ ).

\subsection{Australian PSA samples}

PSA samples from Australia were collected in July 2007 from various loess and soil deposits for which chronologies and geomorphological descriptions have already been reported. The sites sampled include Lake Mungo dunefield (Kershaw and Nanson, 1993), Brachina Gorge (Glasby et al., 2007), Lake Eyre (Magee et al., 2004), Strzelecki desert (Fitzsimmons et al., 2007) and Innamincka/ Tilcha Waterhole (Nanson et al., 2008). These sites represent locations of present dust production or loess deposits, which can be considered isotopically representative of dust produced in previous glacial periods.

\subsection{Other PSA samples}

Lead isotopic compositions were determined in a selection of soil and loess samples previously reported by Delmonte et al. (2004). These samples derive from locations within SSA (in particular from 
the Pampas region and Patagonia), Southern Africa (Namibia), New Zealand (Southland, Otago) and Coastal East Antarctica (Dry Valleys and Northern Victoria Land).

\section{Materials and methods}

\subsection{Ice core samples}

The methods of preparation and analysis of the ice core samples have been previously described (Vallelonga et al., 2002a,b; Gabrielli et al., 2004). To summarize, the decontaminations were carried out in France, within a bench supplied with HEPA-filtered air maintained at $-20^{\circ} \mathrm{C}$ and using acid cleaned polyethylene tools and stainless steel chisels. The samples were decontaminated manually using a chiseling procedure in which the pristine inner core samples were mechanically separated from the outer contaminated layers of each ice core section. Each inner core section was usually broken into two pieces, each approximately $20 \mathrm{~cm}$ long. The decontaminated samples were bottled and sent to Australia for $\mathrm{Pb}$ isotopes analysis by Thermal Ionization Mass Spectrometry (TIMS) using a Fisons Instruments VG-354. Approximately $10 \mathrm{~mL}$ of each inner core sample was evaporated, after the addition of a $\mathrm{HNO}_{3} / \mathrm{HF} /$ $\mathrm{H}_{3} \mathrm{PO}_{4}$ acid mixture and a ${ }^{137} \mathrm{Ba} /{ }^{205} \mathrm{~Pb}$ isotopic tracer solution. Twelve samples were analysed at a time, with blanks and a NIST 981 SRM added to each sample batch for quality control and monitoring of instrumental mass fractionation. The instrumental mass fractionation of $0.24 \pm 0.06 \%$ per mass unit was applied to the measured isotopic ratios. Reported uncertainties on $\mathrm{Pb}$ isotopic compositions in EDC ice are 95\% confidence intervals which represent the combination of uncertainties associated with the sample measurement, the isotopic composition of the Pb blank and the instrumental mass fractionation correction. The total analytical blank was usually $0.4 \mathrm{pg} \mathrm{Pb}$ and $2.5 \mathrm{pg}$ Ba. The accuracy of the $\mathrm{Pb}$ and $\mathrm{Ba}$ concentrations is estimated to be $\pm 10 \%$ (95\% confidence interval), attributed mainly to the accuracy of dispensing the spike into the sample.

\subsection{Australian PSA samples}

Australian PSA samples were initially prepared at University Ca' Foscari of Venice, Italy, then sent to Ghent University, Belgium for $\mathrm{Pb}$ isolation and measurement. The bulk samples were initially dried at $50{ }^{\circ} \mathrm{C}$ for $12 \mathrm{~h}$, then two $0.3 \mathrm{~g}$ aliquots were taken of each sample for treatment by two different methods: extraction and digestion. Each extraction involved adding $8 \mathrm{~mL}$ of $65 \% \mathrm{HNO}_{3}$ and $2 \mathrm{~mL}$ of $30 \% \mathrm{H}_{2} \mathrm{O}_{2}$ to $0.3 \mathrm{~g}$ of sample while each digestion involved adding $6 \mathrm{~mL}$ of $65 \% \mathrm{HNO}_{3}, 3 \mathrm{~mL}$ of $50 \% \mathrm{HF}$ and $2 \mathrm{~mL}$ of $30 \% \mathrm{H}_{2} \mathrm{O}_{2}$ to $0.3 \mathrm{~g}$ of sample. Each extraction and digestion mixture was then microwaved for $2 \mathrm{~h}$. The mixtures were then evaporated and redissolved in $2 \mathrm{~mL}$ of dilute $\mathrm{HBr}$ before being passed through an AG1-X8 anion exchange column. The $\mathrm{Pb}$ was eluted in concentrated $\mathrm{HCl}$, evaporated and then redissolved in $1 \% \mathrm{HNO}_{3}$ solution with $20 \mathrm{ng}$ of NIST $997 \mathrm{SRM}\left({ }^{205} \mathrm{Tl} /{ }^{203} \mathrm{Tl}=2.38714\right)$ added. The samples were then analysed using a ThermoScientific Neptune MC-ICP-MS located at Ghent University. The NIST 997 SRM added to each sample allowed the real-time monitoring of plasma variations and correction of instrumental mass discrimination. Mass discrimination was corrected using the Russell law (White et al., 2000), with total analytical blanks consistently lower than $1 \%$ of the signal intensity of the samples.

\subsection{Other PSA samples}

PSA samples described by Delmonte et al. (2004) were analysed in Australia using TIMS. All fine-particulate samples (total dust mass $<5 \mu \mathrm{m}$ diameter) were isolated by humid sedimentation and checked by coulter counter analysis prior to chemical processing. Three bulk (coarse-grained) samples were also chemically processed. Aliquots of these samples were then evaporated and redissolved in dilute $\mathrm{HBr}$ prior to $\mathrm{Pb}$ isolation by anion exchange chemistry (Dowex AG1-X8, 100-200 mesh). The column was flushed with $0.5 \mathrm{M} \mathrm{HBr}$ with the $\mathrm{Pb}$ then eluted in MQ water. $\mathrm{H}_{3} \mathrm{PO}_{4}$ was added to the sample prior to evaporation, with the evaporated sample then loaded onto a Rhenium filament using silica gel. The samples were then analysed using the aforementioned FISONS Instruments VG-354 TIMS. Total analytical blanks were consistently less than $400 \mathrm{pg} \mathrm{Pb}$, corresponding to less than $0.5 \%$ of the sample size analysed. Coarse-grained PSA samples (SA1, SA3, A7) have not been used to evaluate Antarctic dust provenance because they cannot be considered representative of the $<5 \mu \mathrm{m}$ diameter dust particulates found in Dome C ice.

\section{Results}

\subsection{EDC ice samples}

The preliminary data set of $\mathrm{Pb}$ isotopic compositions reported in 30 samples from EDC has here been extended to 74 samples covering the period 2-217 kyr BP (Table S1, supplemental data). The $\mathrm{Pb}$ and $\mathrm{Ba}$ concentrations (Fig. 1a,b) follow well-defined glacialinterglacial variations, with the lowest concentrations during the Holocene MIS 1 (14 samples, average $0.36 \mathrm{pg} \mathrm{Pb/g,10.2} \mathrm{pg} \mathrm{Ba/g)} \mathrm{and}$ Eemian MIS 5.5 (4 samples, average 0.41 pg Pb/g, 11.2 pg Ba/g) and the highest concentrations during the Last Glacial Maximum (LGM) MIS 2 (10 samples, average $13.4 \mathrm{pg} \mathrm{Pb/g,} 278 \mathrm{pg} \mathrm{Ba} / \mathrm{g}$ ). The data are in good agreement with LGM/Holocene REE concentrations ratios found in the EDC ice core (Gabrielli et al., 2010). A comparison of $\mathrm{Pb}$ and $\mathrm{Ba}$ concentrations to $\delta \mathrm{D}$ demonstrates the well-reported nonlinear sensitivity of dust fallout to climate (Gabrielli et al., 2005), in which low $\mathrm{Pb}$ and $\mathrm{Ba}$ concentrations are observed at warmer temperatures $(\delta \mathrm{D}>-435 \%$ ) while $\mathrm{Pb}$ and $\mathrm{Ba}$ concentrations increase steeply at colder temperatures $(\delta \mathrm{D}<-435 \%$ o $)$. This is in good agreement with the $\delta \mathrm{D}$ value of $-425 \%$ at which Lambert et al. (2008) observed a correlation between dust flux and temperature. Only two samples dated to $53.8 \mathrm{ky}$ BP do not follow this trend by displaying high $\mathrm{Pb}$ and Ba concentrations at a $\delta \mathrm{D}$ value of $-429 \%$ - these samples correspond to the cool climate phase between glacial Antarctic warm events A3 and A4, during which dust fluxes approached LGM levels.

In contrast to the well-defined variations of $\mathrm{Pb}$ and Ba concentrations, a high level of variability is observed in the ${ }^{206} \mathrm{~Pb} /{ }^{207} \mathrm{~Pb}$ profile (Fig. 2). The overall trend matches that previously reported, with low ${ }^{206} \mathrm{~Pb} /{ }^{207} \mathrm{~Pb}$ values during the coldest climate phases followed by higher ${ }^{206} \mathrm{~Pb} /{ }^{207} \mathrm{~Pb}$ during the transitions to warmer climate phases. The level of variability in the data suggests that, for Dome $\mathrm{C}$ ice records, changes in $\mathrm{Pb}$ isotopic compositions need to be evaluated with respect to changes in dust concentration as well as changes in temperature.

Lead isotopic compositions in the EDC samples are also consistent with the preliminary data set reported by Vallelonga et al. (2005), being distributed along a mixing line between two end-members. Fig. 3 shows that this mixing line is common to all pre-industrial Antarctic ice and snow samples reported, with a radiogenic endmember of ${ }^{206} \mathrm{~Pb} /{ }^{207} \mathrm{~Pb} \sim 1.27$ and ${ }^{208} \mathrm{~Pb} /{ }^{207} \mathrm{~Pb} \sim 2.52$ (the most radiogenic Taylor Dome sample) and a relatively unradiogenic endmember of ${ }^{206} \mathrm{~Pb} /{ }^{207} \mathrm{~Pb} \sim 1.17$ and ${ }^{208} \mathrm{~Pb} /{ }^{207} \mathrm{~Pb} \sim 2.44$ (the least radiogenic Coats Land samples). Lead isotopic compositions in Antarctic ice and snow samples are distributed according to location, with $\mathrm{Pb}$ from Taylor Dome (Matsumoto and Hinkley, 2001) and Law Dome (Vallelonga et al., 2002a,b) generally being more radiogenic 


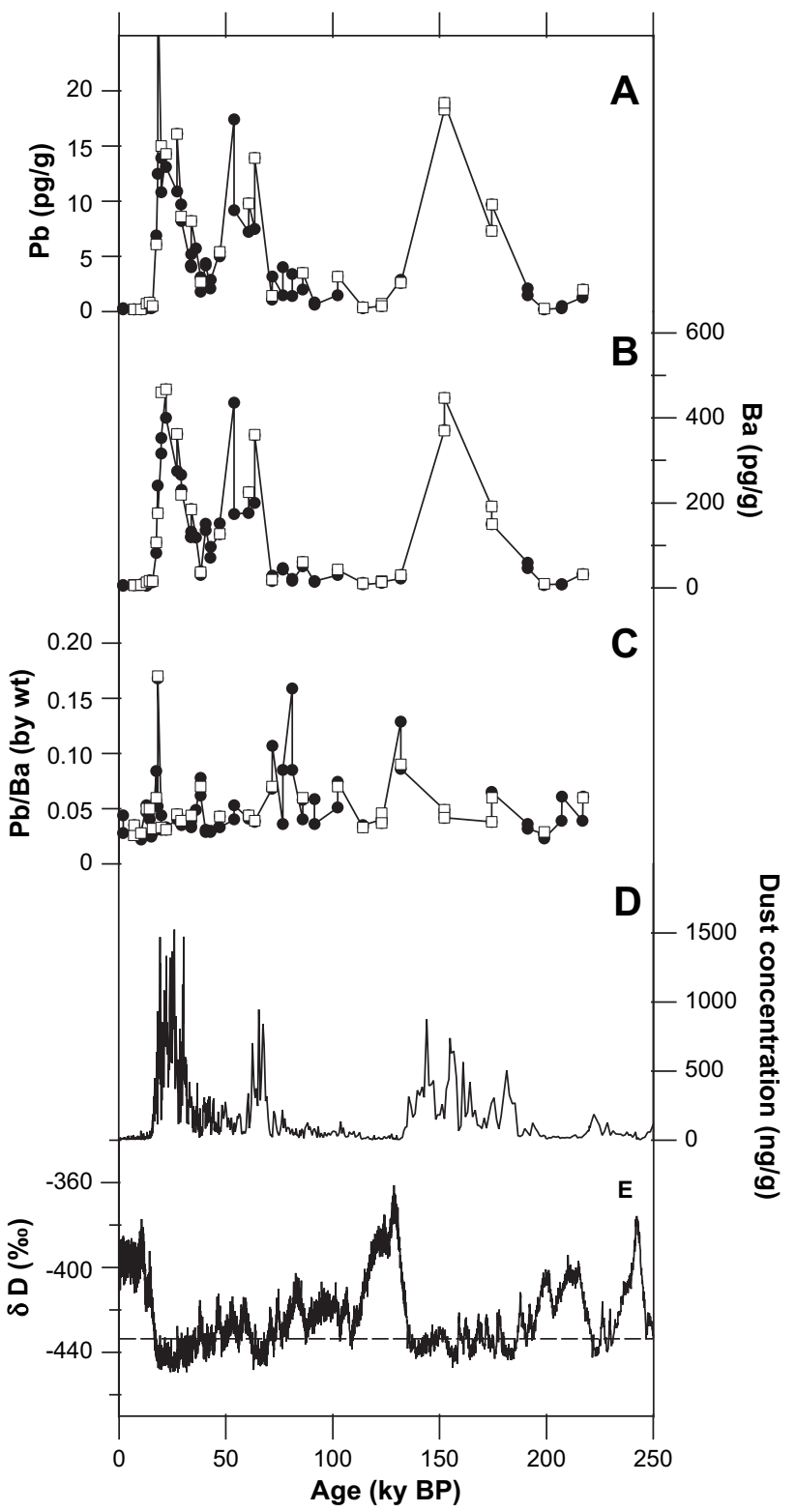

Fig. 1. Variations in concentrations of $\mathrm{Pb}(\mathrm{A})$ and $\mathrm{Ba}(\mathrm{B}), \mathrm{Pb} / \mathrm{Ba}$ ratios (C), dust concentrations (D) and $\delta \mathrm{D}(\mathrm{E})$ in EPICA Dome $C$ ice core. Filled circles indicate new data (this work) and hollow squares indicate previously reported data (Vallelonga et al., 2005). The horizontal dashed line indicates a $\delta \mathrm{D}$ value of $-435 \%$ : below this temperature $\mathrm{Pb}$ and $\mathrm{Ba}$ concentrations increase rapidly. The $\delta \mathrm{D}$ data are from Jouzel et al. (2007). Dust concentrations were determined by Coulter counter as reported by Lambert et al. (2008). The accuracies of the $\mathrm{Pb}$ and Ba concentrations are described in the main text.

than that from EDC or Coats Land (Planchon et al., 2003). Considering the distribution of $\mathrm{Pb}$ isotopic compositions in Antarctic ice samples, two Coats Land samples appear to be anomalously unradiogenic, but these two samples (dated to 1846 AD and 1851 AD) feature very low $\mathrm{Pb}$ concentrations and consequently large uncertainties were reported for their $\mathrm{Pb}$ isotopic compositions.

The overall trend of the data is consistent with that reported previously, with more-radiogenic $\mathrm{Pb}$ signatures during warmer climatic periods and less-radiogenic values during colder climate periods, but there appears to be a substantial level of variability. This is most clearly demonstrated by comparing $\delta \mathrm{D}$, a paleotemperature proxy, with ${ }^{206} \mathrm{~Pb} /{ }^{207} \mathrm{~Pb}$ isotope ratio (Fig. 4). It is clear that for most climate temperature conditions, ${ }^{206} \mathrm{~Pb} /{ }^{207} \mathrm{~Pb}$ values vary between $\sim 1.19$ and $\sim 1.24$. It is only for $\delta \mathrm{D}$ values below $-432 \%$ that the distribution of ${ }^{206} \mathrm{~Pb} /{ }^{207} \mathrm{~Pb}$ values narrows, decreasing consistently within the smaller range of values between 1.19 and 1.21. These paleotemperatures correspond to the coldest climatic conditions, when dust fluxes are at their maximum.

\subsection{Australian PSA samples}

Lead isotopic compositions in PSA samples from Australia display intermediate values, not dissimilar to Southern South American PSAs but less-radiogenic than the Antarctic McMurdoErebus volcanic province. Australian PSA data are reported in Table S2(supplemental data). As shown in Fig. 5a, the HF-digested samples ( ${ }^{206} \mathrm{~Pb} /{ }^{207} \mathrm{~Pb}$ : $1.175-1.195,{ }^{208} \mathrm{~Pb} /{ }^{207} \mathrm{~Pb}$ : $2.49-2.53$ ), representing the large-grained silicate fraction, can be distinguished from the extracted fine-fraction of these samples $\left({ }^{206} \mathrm{~Pb} /{ }^{207} \mathrm{~Pb}\right.$ : $\left.1.19-1.24,{ }^{208} \mathrm{~Pb} /{ }^{207} \mathrm{~Pb}: 2.47-2.55\right)$ which are more radiogenic, exhibiting greater ${ }^{206} \mathrm{~Pb} /{ }^{207} \mathrm{~Pb}$ and ${ }^{208} \mathrm{~Pb} /{ }^{207} \mathrm{~Pb}$ values. This is most extreme in the case of the two samples from Brachina Gorge $\left({ }^{206} \mathrm{~Pb} /{ }^{207} \mathrm{~Pb} \sim 1.24,{ }^{208} \mathrm{~Pb} /{ }^{207} \mathrm{~Pb} \sim 2.55\right)$, which have quite radiogenic values. This Th-rich signature is compatible with $\mathrm{Pb}$ isotopic compositions reported for source rocks in Northern Australia (Bollhöfer et al., 2006). Of the Australian PSA samples only the extracted fine-fraction data have been used to evaluate Antarctic dust provenance.

\subsection{Other PSA samples}

With the exception of Antarctic PSA samples, Pb isotopic compositions of the PSA regions are well constrained and show only minor variations (Table S3, supplemental data). Southern African samples display relatively unradiogenic values $\left({ }^{206} \mathrm{~Pb} /{ }^{207} \mathrm{~Pb}: 1.194-1.200\right.$, $\left.{ }^{208} \mathrm{~Pb} /{ }^{207} \mathrm{~Pb}: 2.452-2.463\right)$ while Southern South American samples $\left({ }^{206} \mathrm{~Pb} /{ }^{207} \mathrm{~Pb}: 1.193-1.199,{ }^{208} \mathrm{~Pb} /{ }^{207} \mathrm{~Pb}: 2.460-2.477\right)$ overlap with those of New Zealand which have more-radiogenic values $\left({ }^{206} \mathrm{~Pb} /{ }^{207} \mathrm{~Pb}: 1.197-1.208,{ }^{208} \mathrm{~Pb} /{ }^{207} \mathrm{~Pb}: 2.470-2.484\right)$. These samples are generally similar in ${ }^{206} \mathrm{~Pb} /{ }^{207} \mathrm{~Pb}$ ratio to those from Australia, but with lower ${ }^{208} \mathrm{~Pb} /{ }^{207} \mathrm{~Pb}$ values, indicating more Th in Australian source rocks. The Antarctic samples display quite large variations in $\mathrm{Pb}$ isotopic composition even though they were sampled within a relatively small area between Ross Island, the adjacent Dry Valleys and Northern Victoria Land (NVL). Dividing the samples according to their East-West locations, the three $\mathrm{Pb}$ isotopic signatures observed are: 1) a pure volcanic signature $\left({ }^{206} \mathrm{~Pb} /{ }^{207} \mathrm{~Pb}\right.$ : $1.251-1.262$, ${ }^{208} \mathrm{~Pb} /{ }^{207} \mathrm{~Pb}: 2.488-2.518$ ) corresponding to the McMurdo-Erebus volcanic field [Corroborated with $\mathrm{Sr}$ and Nd isotopic data (Sims et al., 2008)]; 2) a less-radiogenic signature from Northern Victoria Land $\left({ }^{206} \mathrm{~Pb} /{ }^{207} \mathrm{~Pb}: 1.174-1.189,{ }^{208} \mathrm{~Pb} /{ }^{207} \mathrm{~Pb}: 2.467-2.475\right)$ similar to those of Southern South America and Australia which has not been previously identified, and 3) a Th-rich signature $\left({ }^{206} \mathrm{~Pb} /{ }^{207} \mathrm{~Pb}: 1.197-1.199\right.$, ${ }^{208} \mathrm{~Pb} /{ }^{207} \mathrm{~Pb}$ : 2.523-2.606) from Pearse Valley, similar to that reported by De Paolo et al. (1982) for rocks from Enderby Land in East Antarctica.

Lead isotopes in fine-grained and coarse-grained PSA samples do indicate some minor variation in isotopic composition, which may be attributable the specific characteristics of the sampling locations. Only two Southern South American and one Antarctic sample are available for comparison, with divergent trends: the two Southern South American fine-grained samples have lessradiogenic signatures compared to the bulk samples, while for Antarctica the fine-grained PSA sample has a more-radiogenic signature compared to the bulk sample. These different trends can be explained by considering the different conditions in which these samples were collected. In Southern South America, the finegrained fraction would be more susceptible to anthropogenic $\mathrm{Pb}$ 


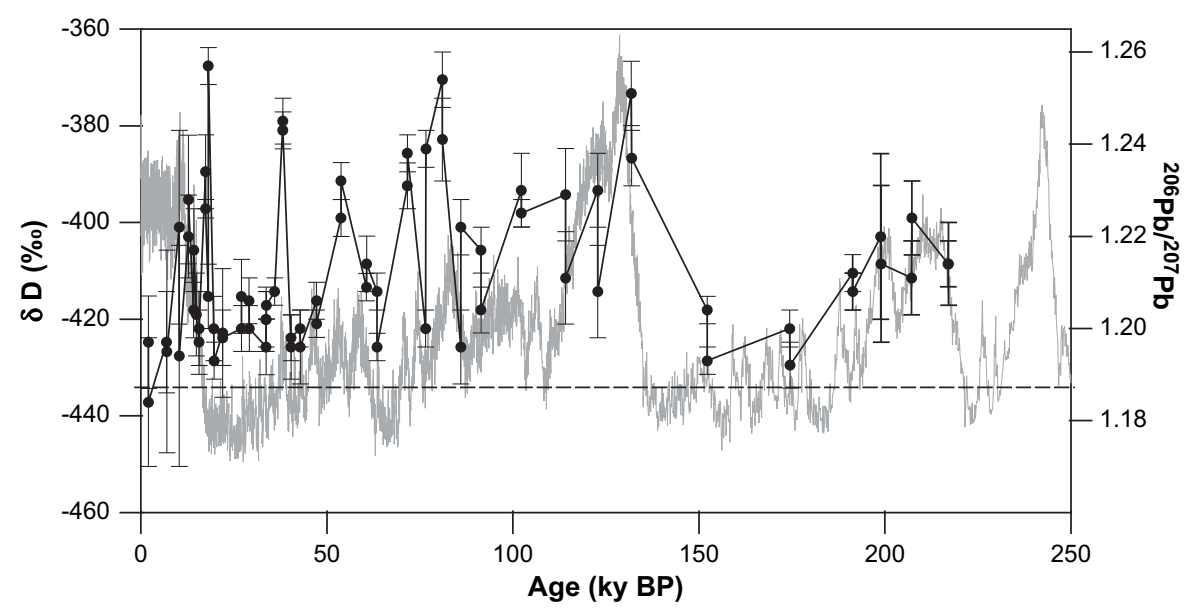

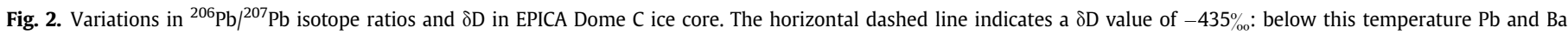
concentrations increase rapidly. The $\delta \mathrm{D}$ data are from Jouzel et al. (2007). All uncertainties are $95 \%$ confidence intervals.

from leaded petrol and industrial emissions, which is reasonably unradiogenic (Bollhöfer and Rosman, 2000). In the Victoria Land region of Antarctica, the fine-grained fraction would be more susceptible to influence from local, highly radiogenic, $\mathrm{Pb}$ sources such as Mount Erebus. Coarse-grained PSA samples (SA1, SA3, A7) have not been used to evaluate Antarctic dust provenance because they cannot be considered representative of the $<5 \mu \mathrm{m}$ diameter dust particulates found in Dome $C$ ice.

\section{Discussion}

\subsection{Sources of $\mathrm{Pb}$ in pre-industrial Antarctic ice}

Hinkley (2007) recently reviewed the sources of natural $\mathrm{Pb}$ in Antarctica based on $\mathrm{Pb}$ isotopic compositions reported in Taylor Dome, EDC, Law Dome, Victoria Land and Coats Land. It was reported that in most of these locations, dust inputs (usually based on Ba concentrations) could only account for a minor proportion of total $\mathrm{Pb}$ in the ice, and that the remainder of the $\mathrm{Pb}$ originates from a radiogenic source compatible with the isotopic signatures of worldwide ocean volcanoes and some Antarctic volcanoes. Of the samples used to formulate this argument, the EDC samples show the greatest proportion of $\mathrm{Pb}$ from dust. This argument is supported further by the $\mathrm{Pb}$ isotopic compositions observed in Antarctic ice from all locations studied - Pb signatures do not vary from a broad mixing line between PSA signatures of mineral dust and McMurdoprovince volcanic signatures (Fig. 5b). Rosman et al. (1998) reported the only pre-industrial Antarctic ice sample for which an extreme deviation from this trend was observed: ice from Law Dome with a markedly high ${ }^{208} \mathrm{~Pb} /{ }^{207} \mathrm{~Pb}$ ratio of 2.784 indicative of a Th-rich source such as those identified in Antarctica [Pearce Valley (this work); Enderby Land (De Paolo et al., 1982)] or Australia (Bollhöfer et al., 2006).

As with $\mathrm{Sr}$ and $\mathrm{Nd}$, variations in $\mathrm{Pb}$ isotopic compositions of different geographical regions of dust production potentially allow the application of this element for dust provenance studies. Hinkley (2007) identified a potential limitation of the $\mathrm{Pb}$ isotopic system for dust provenance, in that the $\mathrm{Pb}$ found in Antarctic ice does not originate solely from dust but also from quiescent volcanism. This is evident in the distribution of $\mathrm{Pb}$ isotopes in Antarctic ice in Fig. 3, along a mixing line with a radiogenic volcanic $\mathrm{Pb}$ end-member and a less-radiogenic dust- $\mathrm{Pb}$ end-member. Considering that different locations in Antarctica display different proportions of volcanic $\mathrm{Pb}$ and dust $\mathrm{Pb}$, those locations which display the greatest proportion of dust $\mathrm{Pb}$ are likely to offer the best opportunity for dust provenance using $\mathrm{Pb}$ isotopes. When volcanic $\mathrm{Pb}$ is present in Antarctic ice, the $\mathrm{Pb}$ isotopic composition determined reflects a mixture of the dominant source (or mixture of sources) of dust and the characteristic radiogenic signature of volcanic $\mathrm{Pb}$. While this does not inhibit the evaluation of the $\mathrm{Pb}$ isotopic signature of the predominant Antarctic dust source in EDC samples, it does limit the potential for identifying minor dust sources, particularly during interglacial climate phases when dust-Pb concentrations are low. Minor dust sources can only be identified as a deviation from the predominant mixture of volcanic and dust- $\mathrm{Pb}$ sources, requiring that the isotopic signature of the minor dust source is distinct from that of the predominant dust source and/or that the analytical precision is sufficient to resolve variations in $\mathrm{Pb}$ isotopic composition from one ice sample to the next. Currently, the required analytical precision cannot be achieved for the low $\mathrm{Pb}$ concentrations found in Antarctic ice, but new analytical techniques such as multiple ion collectors may lead to advancements in this field (Wieser and Schwieters, 2005). In Sections 5.4 and 5.5, the distinctiveness of the Australian and Antarctic PSA signatures are considered in terms of identifying minor dust contributions to Antarctica.

\subsection{Glacial-interglacial changes in $\mathrm{Pb}$ isotopic compositions}

Variability in the $\mathrm{Pb}$ isotopic composition of Antarctic dust is primarily dependent on dust concentrations that, in turn, are related to changes in climate. While the observed $\mathrm{Pb}$ isotopic composition results from a combination of volcanic and dust signatures, the overwhelming influence of dust sources during glacial maxima and other cold climatic periods ensures the predominance of dust- $\mathrm{Pb}$ signatures which are in correspondence with the isotopic signature of Southern South American PSAs. These periods of high dust concentration are characterized by $\delta \mathrm{D}$ values less than $-435 \%$ which is the value corresponding to a sharp increase in dust concentration with decreasing temperature.

The climatic periods characterized by low dust concentrations cannot be distinguished from those corresponding to high dust concentrations on the basis of $\mathrm{Pb}$ isotopic compositions. Low dust concentrations occurred during either warm (interglacial or interstadial) temperatures or intermediate/cool (glacial) temperatures for which $\delta \mathrm{D}>-435 \%$. Lambert et al. (2008) also observed that the relation between dust and climate is much less sensitive at intermediate and warm temperatures and linked this relation to the 


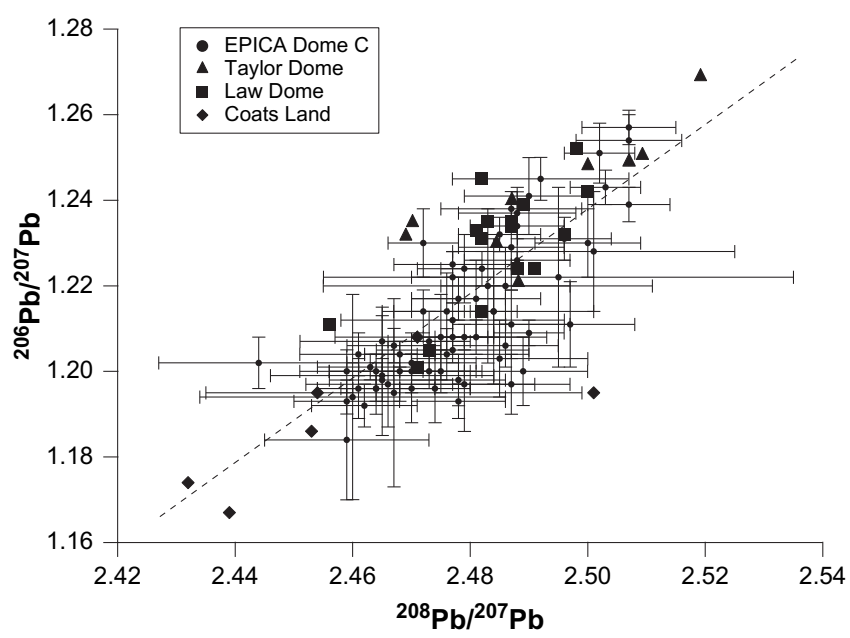

Fig. 3. Lead isotopic compositions in pre-industrial Antarctic ice from EPICA Dome $C$ (this work), Coats Land (Planchon et al., 2003), Law Dome (Vallelonga et al., 2002a,b) and Taylor Dome (Matsumoto and Hinkley, 2001). The dotted line indicates a leastsquares regression fit for all locations $\left[\left({ }^{206} \mathrm{~Pb} /{ }^{207} \mathrm{~Pb}\right)=1.009 \times\left({ }^{208} \mathrm{~Pb} /{ }^{207} \mathrm{~Pb}\right)-1.285\right.$; $\left.r^{2}=0.63\right]$ but is not intended to accurately represent the locations of volcanic (radiogenic) and dust (less radiogenic) mixing-line end-members. All uncertainties are $95 \%$ confidence intervals.

movement of westerly atmospheric circulation patterns and reduced extent of Antarctic sea ice. As shown in Fig. 4 and discussed in this section, average ${ }^{206} \mathrm{~Pb} /{ }^{207} \mathrm{~Pb}$ values in samples with $\delta \mathrm{D}>-435 \%$ are statistically indistinguishable from samples corresponding to cold climate phases. The samples corresponding to warmer temperatures have a greater average value and more variability: ${ }^{206} \mathrm{~Pb} /{ }^{207} \mathrm{~Pb}$ values average $1.201 \pm 0.011$ for samples with $\delta \mathrm{D}<-435 \%$ and $1.217 \pm 0.034$ for samples with $\delta \mathrm{D}>-435 \%$ ( $2 \sigma$ uncertainties). The greater ${ }^{206} \mathrm{~Pb} /{ }^{207} \mathrm{~Pb}$ average observed in samples deposited during warmer temperatures is due to the radiogenic character of volcanic $\mathrm{Pb}$, the inputs of which can be quantified via the sample $\mathrm{Pb} / \mathrm{Ba}$ ratio. Of the samples corresponding to warm or intermediate climate phases $(\delta \mathrm{D}>-435 \%$ ), those with

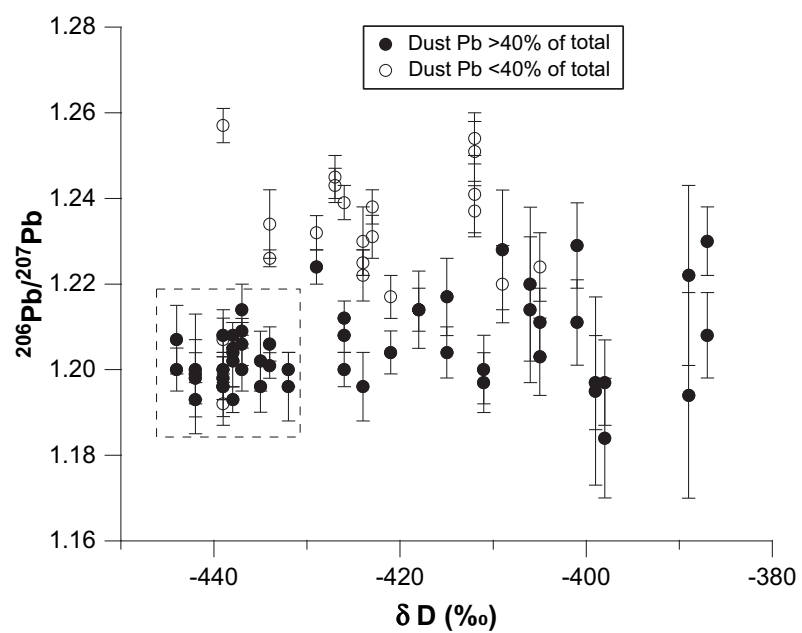

Fig. 4. Comparison of ${ }^{206} \mathrm{~Pb} /{ }^{207} \mathrm{~Pb}$ isotope ratios with $\delta \mathrm{D}$ values in EPICA Dome $\mathrm{C}$ ice core. Empty circles indicate samples that contain less than $40 \%$ dust $\mathrm{Pb}(\mathrm{Pb} / \mathrm{Ba}>0.075)$. Samples from colder climatic periods (located within the dotted lines) display less variability in ${ }^{206} \mathrm{~Pb} /{ }^{207} \mathrm{~Pb}$ compared to samples from warmer periods. The sample with $\delta \mathrm{D}=-439 \%$ and ${ }^{206} \mathrm{~Pb} /{ }^{207} \mathrm{~Pb}=1.257$ corresponds to an identified volcanic deposition event. The $\delta \mathrm{D}$ data are from Jouzel et al. (2007). All uncertainties are 95\% confidence intervals. dust- $\mathrm{Pb}$ inputs greater than $40 \%$ have similar ${ }^{206} \mathrm{~Pb} /{ }^{207} \mathrm{~Pb}$ values $(1.205 \pm 0.020)$ to the samples from cold climate phases - these samples are represented by filled circles in Fig. 4. The wider ranges of ${ }^{206} \mathrm{~Pb} /{ }^{207} \mathrm{~Pb}$ values observed during warmer climate periods suggests greater variability in dust sources at those times. As may be expected, the ${ }^{206} \mathrm{~Pb} /{ }^{207} \mathrm{~Pb}$ signature of samples containing mostly ( $>60 \%$ ) volcanic $\mathrm{Pb}$ is consistently radiogenic irrespective of temperature. While glacial-interglacial variations in the composition of Antarctic dust sources have been suggested by Delmonte et al. (2008) and Lambert et al. (2008), among others, the influence of volcanic $\mathrm{Pb}$ during interglacial climate phases inhibits the identification of such variations using $\mathrm{Pb}$ isotope signatures.

\subsection{Sources of dust $\mathrm{Pb}$ in Antarctica}

As has been recently summarized by Delmonte et al. (2008), ongoing geochemical, geophysical and modelling research suggests Southern South America to be the predominant source of Antarctic dust during glacial climate phases. Lead isotopic signatures in Antarctic ice and PSAs support this contention, based upon the correspondence between the non-radiogenic end-member of isotopic signatures in EDC samples $\left({ }^{206} \mathrm{~Pb} /{ }^{207} \mathrm{~Pb} \sim 1.19\right.$ and ${ }^{208} \mathrm{~Pb} /{ }^{207} \mathrm{~Pb} \sim 2.46$ ) and the $\mathrm{Pb}$ isotopic compositions identified in Southern South American samples. While Pb isotopic signatures of some other PSAs do overlap with those of Southern South America, each of these regions can be discounted from consideration as the predominant source of dust supplied to Antarctica: the digested Australian PSA samples can be excluded from consideration because they correspond to coarse-grained particles (predominantly silicates) which are unlikely to be successfully transported to Antarctica. This is confirmed by dust particle sizes in EDC, which have a mode around $2 \mu \mathrm{m}$ in diameter (Lambert et al., 2008). South African PSAs occupy a restricted range with low ${ }^{208} \mathrm{~Pb} /{ }^{207} \mathrm{~Pb}$ values $<2.46$ (indicating Th-depleted basement rock) that cannot uniquely account for the range of $\mathrm{Pb}$ isotopic compositions observed in EDC ice $\left({ }^{208} \mathrm{~Pb} /{ }^{207} \mathrm{~Pb}\right.$ values from 2.44 to 2.49$)$. Similarly, the limited surface area and likely limited scale of dust production would exclude New Zealand from being the predominant source of Antarctic dust (Delmonte et al., 2004), before PSA isotopic signatures are considered. In the case of New Zealand, all samples fall within the field defined by Southern South American PSAs as well as Australia coarse-grained particles, so these sources cannot be distinguished isotopically. The widespread distribution of $\mathrm{Pb}$ isotopic signatures in PSAs corresponding to local Antarctic dust sources is discussed in Section 5.5.

While the aforementioned arguments have been applied to compensate for the superposition of $\mathrm{Pb}$ isotopic signatures in PSAs from SSA, New Zealand and Southern Africa, there is an ongoing need to accurately quantify the dust fluxes from each region as well as to determine representative $\mathrm{Pb}$ isotopic signatures. Only three samples have been measured to represent Southern Africa or New Zealand, which are of utility as an indicative signature but should not be considered a conclusive description of the diverse geologies of these regions (Mackie et al., 2008, p. 16). In a similar fashion, the Southern South American PSA samples analysed here do not represent recently identified regions of dust production such as the Puna-Altiplano Plateau reported by Gaiero (2007) and so may not be considered representative of all dust sources within that continent. The discrepancy in $\mathrm{Pb}$ isotopic signatures between the Southern South American PSA samples reported here and South Atlantic Ocean pelagic sediments (Chow and Patterson, 1962) is another indication that further work is required to reliably characterize PSA sources in Southern South America. Mixing of PSAs from different regions should also be considered: for example Marx et al. (2005) showed that substantial quantities of dust deflated 


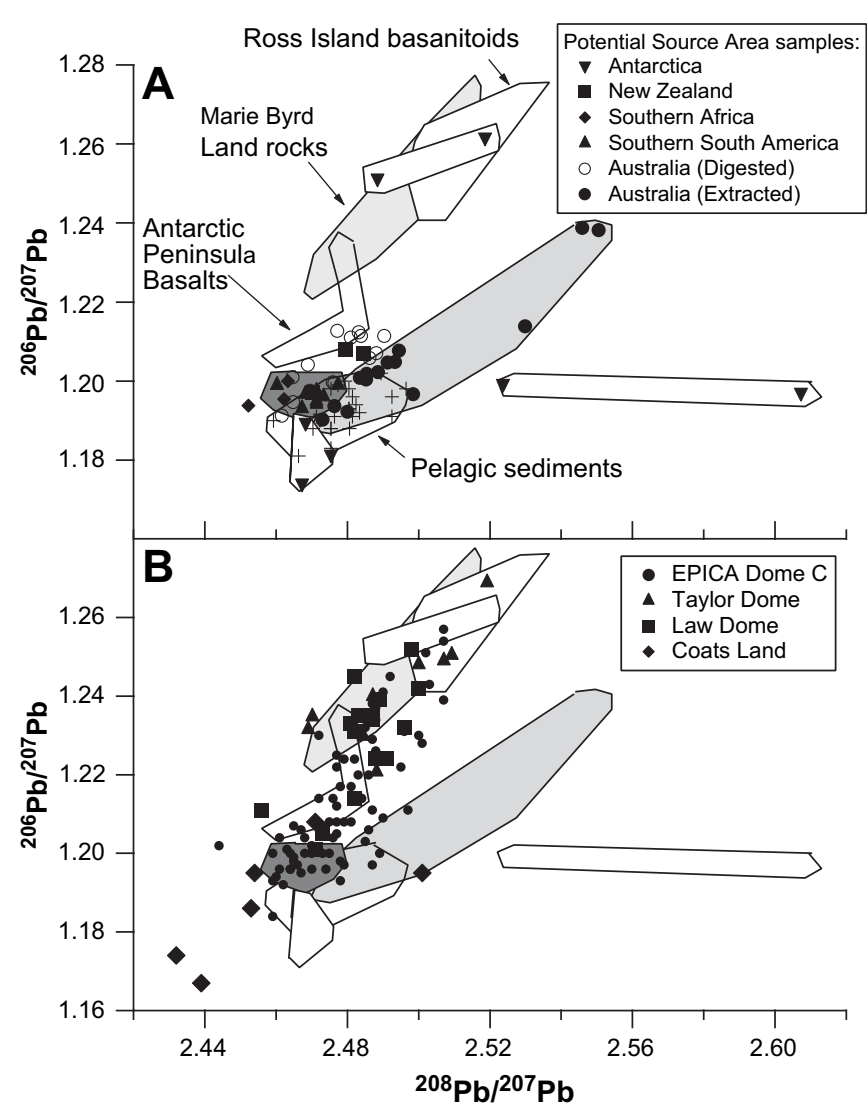

Fig. 5. A: lead isotopic compositions in PSA samples from the Southern Hemisphere (this work) and other proxies of dust and volcanic Pb signatures. Also shown are South Atlantic and South Pacific Ocean pelagic sediments (Chow and Patterson, 1962), Ross Island basanitoids (Sun and Hanson, 1975), Marie Byrd Land rocks (Hart et al., 1997) and Antarctic Peninsula basalts (Hole et al., 1993). Error bars for the PSA samples reported here are smaller than the image symbols shown. B: lead isotopic compositions of Antarctic firn and ice core samples from Fig. 3 compared to the PSA fields shown in Fig. 5a.

from Australia are transported to New Zealand and so may mix with dust deflated from New Zealand, or alter the signature of PSA samples collected from New Zealand. Recent modelling (Li et al., 2008) also indicates some level of mixing of continental dust sources in the Southern Hemisphere. Ultimately, attempts should be made to compare regional PSAs with aerosols collected in remote locations of the Southern Ocean as well as Antarctica, to more accurately characterize the dust transported to Antarctica.

\subsection{Australian dust in Antarctica}

Recent geochemical and modelling studies indicate that Eastern Australia may be a non-trivial source of dust deposition during interglacial climate phases. Revel-Rolland et al. (2006) showed that $\mathrm{Sr}$ and Nd isotopic compositions of Eastern Australian PSA samples are similar to $\mathrm{Sr}$ and $\mathrm{Nd}$ signatures in interglacial ice from Vostok and EDC, while modelling by Li et al. (2008) also indicates the importance of Australia as a source of dust to Antarctica as well as the Pacific Ocean and Eastern sector of the Southern Ocean. The fine fraction of Australian PSAs (here determined by chemical solubility rather than size-filtering) available to weathering and aeolian deflation are characterized by radiogenic ${ }^{208} \mathrm{~Pb} /{ }^{207} \mathrm{~Pb}$ ratios that are offset from the bulk of the Pb signatures identified in EDC ice. The orientation of the majority of EDC samples (66 of 74) away from the Australian PSA field suggests that Australian dust is not the main component of dust deposited in Antarctic ice. Some Australian PSAs overlap with Southern South American PSAs as well as signatures in some EDC samples, allowing the possibility of Australian dust as a minor component, but as discussed in Section 5.1 this possibility cannot be quantified with the available analytical precision because these samples cannot be distinguished isotopically from the bulk of EDC samples. Of those EDC samples that display an isotopic composition overlapping with the Australian PSA field ( 8 of 74), five of these correspond to interglacials (Holocene: 6.93, 14.91, 15.61, 15.63 ky BP and Eemian: $114.14 \mathrm{ky} \mathrm{BP}$ ) and three correspond to the LGM (19.66, 21.97, 29.09 ky BP), precluding any systematic climaterelated influence. Given the relative similarity of Australian and Southern South American PSA signatures, greater analytical precision will be required to allow $\mathrm{Pb}$ isotope-based elucidation of Australian dust inputs to central Antarctica during the most recent glacial cycles.

\subsection{Local sources of dust in Antarctica}

The $\mathrm{Pb}$ isotopic signatures observed in Antarctic PSAs cover a broad range and can be categorized in three types previously described in Section 4.3 - radiogenic (McMurdo province), relatively unradiogenic (NVL) and Th-rich (Pearse valley). As noted in Section 5.3, relatively few samples are available to define these PSA fields so more extensive sampling will be required to corroborate our findings. While EDC samples show no influence from the Th-rich Pearse valley signature, which would be readily observed by an enhanced ${ }^{208} \mathrm{~Pb} /{ }^{207} \mathrm{~Pb}$ ratio, the influence of the relatively unradiogenic NVL signatures in the samples cannot be dismissed on isotopic arguments alone. While Delmonte et al. (2004) noted that "geochemical and atmospheric circulation parameters support the contention that dust from the Antarctic Dry Valleys is unlikely to be deflated in sufficient quantity, or transported efficiently enough, to account for a substantial proportion of the dust flux observed in central Eastern Antarctica", evidence exists for minor contributions of dust from local Antarctic sources to central Antarctica (Lanci et al., 2008). The distribution and geochemical characteristics of this Antarctic PSA source with such an unusually unradiogenic $\mathrm{Pb}$ signature demand further investigation.

An evaluation of ${ }^{206} \mathrm{~Pb} /{ }^{207} \mathrm{~Pb}$ and $\mathrm{Pb} / \mathrm{Ba}$ ratios in the EDC samples does indicate that dust of local Antarctic origin could be present as a minor component. This data is presented in Fig. 6 , with the $\mathrm{Pb} / \mathrm{Ba}$ value used to indicate the ratio of total $\mathrm{Pb}$ to dust $\mathrm{Pb}$ (which can be calculated from Ba concentrations) and the ${ }^{206} \mathrm{~Pb} /{ }^{207} \mathrm{~Pb}$ ratio indicating Southern South American dust sources (low values 1.20) or McMurdo-province volcanic $\mathrm{Pb}$ sources (values $>1.24$ ). The trend of the data is toward greater ${ }^{206} \mathrm{~Pb} /{ }^{207} \mathrm{~Pb}$ ratios with increasing $\mathrm{Pb} / \mathrm{Ba}$ ratio, which supports the model advanced by Hinkley (2007) in which radiogenic volcanic $\mathrm{Pb}$ is entrained in Antarctic snow as a physically distinct matrix to dust particles which contain also $\mathrm{Ba}, \mathrm{Al}$ and other major and minor elements of the upper crust. Samples containing $\mathrm{Pb} / \mathrm{Ba}$ ratios $>0.09$, which corresponds to a dust- $\mathrm{Pb}$ fraction of $33 \%$, always feature radiogenic $\mathrm{Pb}$ signatures $>1.23$ while a broader range of ${ }^{206} \mathrm{~Pb} /{ }^{207} \mathrm{~Pb}$ ratios was found in samples with lower $\mathrm{Pb} / \mathrm{Ba}$ ratios. A concentration of samples around crustal $\mathrm{Pb} / \mathrm{Ba}$ ratios of $0.025-0.045$ and ${ }^{206} \mathrm{~Pb} /{ }^{207} \mathrm{~Pb}$ ratios of $1.19-1.21$ indicate the predominant source of dust $\mathrm{Pb}$ to EDC, which is compatible with PSA signatures from Southern South America. The EDC samples which indicate a $>50 \%$ input from such a local Antarctic dust source correspond to interglacial periods $(10.27,12.82,114.12,122.81 \mathrm{ky} \mathrm{BP})$ or other phases of minimal dust flux $(38.16,102.25,198.89 \mathrm{ky} \mathrm{BP})$ at EDC. Only one of the samples featuring a $>50 \%$ contribution from local Antarctic dust corresponds to a period of enhanced dust flux, in this case MIS 4.2 (53.83 ky BP). It is not possible to apply a similar evaluation to samples from Taylor Dome or Law Dome because they 


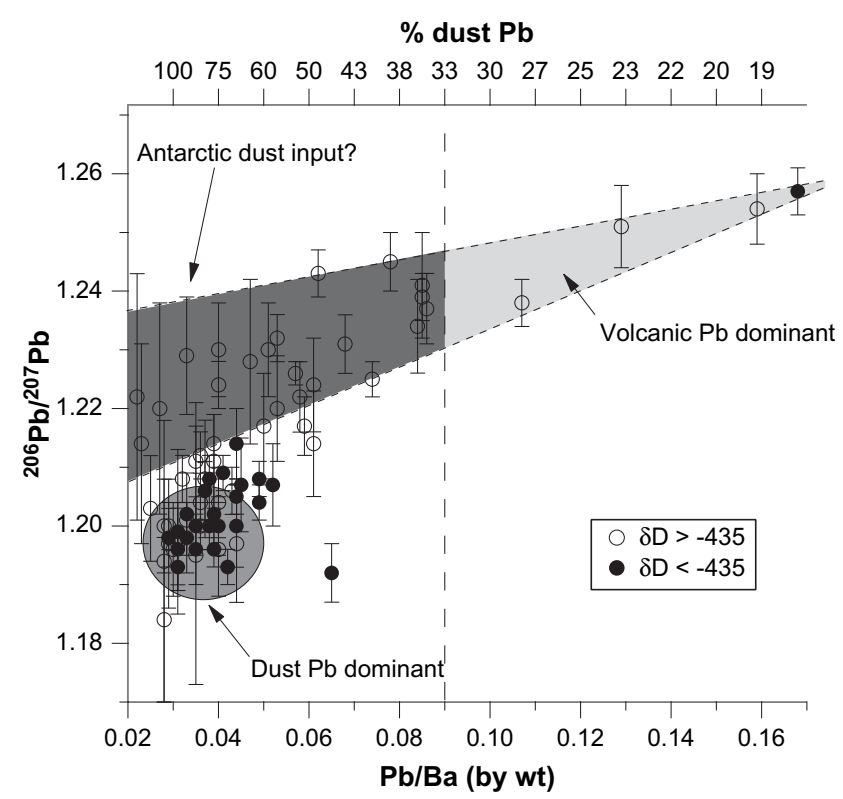

Fig. 6. Comparison of ${ }^{206} \mathrm{~Pb} /{ }^{207} \mathrm{~Pb}$ isotope ratios with $\mathrm{Pb} / \mathrm{Ba}$ ratios in EPICA Dome $\mathrm{C}$ ice core. The samples are differentiated by temperature from colder (filled circles) to warmer (empty circles) climate phases, based on the $\delta \mathrm{D}$ value below which $\mathrm{Pb}$ and $\mathrm{Ba}$ concentrations were observed to increase rapidly $(-435 \%$ ). Samples with greater $\mathrm{Pb} /$ $\mathrm{Ba}$ and ${ }^{206} \mathrm{~Pb} /{ }^{207} \mathrm{~Pb}$ values reflect a dominant volcanic $\mathrm{Pb}$ source. Samples in the grey circle, with lower $\mathrm{Pb} / \mathrm{Ba}$ and ${ }^{206} \mathrm{~Pb} /{ }^{207} \mathrm{~Pb}$ values, reflect a dominant dust- $\mathrm{Pb}$ source. The dotted vertical line corresponds to a $\mathrm{Pb} / \mathrm{Ba}$ ratio of 0.09 , at which point dust $\mathrm{Pb}$ accounts for only $33 \%$ of total $\mathrm{Pb}$ in the ice samples. The presence of samples with low $\mathrm{Pb} /$ Ba but high ${ }^{206} \mathrm{~Pb} /{ }^{207} \mathrm{~Pb}$ ratios suggests a possible local Antarctic dust source. All uncertainties are $95 \%$ confidence intervals.

often display $\mathrm{Pb} / \mathrm{Ba}$ ratios greater than 0.09 and so their isotopic signatures are dominated by volcanic $\mathrm{Pb}$.

EDC samples with $\mathrm{Pb} / \mathrm{Ba}$ ratios of 0.02-0.04 have dust-dominated compositions, but some samples within this $\mathrm{Pb} / \mathrm{Ba}$ range also feature radiogenic ${ }^{206} \mathrm{~Pb} /{ }^{207} \mathrm{~Pb}$ signatures that can only be explained by local Antarctic dust sources such as that characterized by the McMurdo-province PSA samples. This supports the findings of Lanci et al. (2008) who used isothermal remanent magnetization to identify highly magnetic dust, such as those from local Antarctic soils or volcanic terrains, in EDC ice during interglacial phases. It is important to distinguish between the two Antarctic, radiogenic $\mathrm{Pb}$ signatures discussed here: the first originates directly from quiescent degassing of volcanoes (Antarctic or Ocean Islands), while the second is a dust source (or sources) of radiogenic nature located within Antarctica, in the Antarctic Peninsula - Transantarctic Mountains - Victoria Land area. The deposition mechanism of $\mathrm{Pb}$ produced from quiescent volcanism could consist of direct deposition on surface snow and/or adsorption onto dust particles that are then deposited on surface snow. Variable amounts of adsorption of quiescently degassed $\mathrm{Pb}$ may explain the different proportions of volcanic and dust $\mathrm{Pb}$ found in EDC ice within each distinct climate phase.

\section{Conclusions}

Lead isotopic data presented here support the contention that Southern South America is an important source of dust deposited in Antarctic ice and indicate that during interglacial periods and other times of minimal dust flux, Antarctica may be a non-negligible dust source. These data suggest that Australian PSAs are not a major component of Antarctic dust but do not allow a quantifiable evaluation, due to the partial overlap of Australian and Southern South
American PSA signatures as well as the persistent influence of volcanic $\mathrm{Pb}$. Partial overlaps exist for the $\mathrm{Pb}$ isotopic signatures of Southern South American, Australian, Southern African and New Zealand PSAs, demanding better evaluations of those sampling locations that can be considered credible dust sources. Three different geochemical signatures can be observed in Antarctic PSA samples, which can be related to the McMurdo volcanic province, a Th-rich source associated with Pearse Valley and Enderby Land, and a relatively unradiogenic source from Northern Victoria Land that has not been previously observed. Improved analytical precision of $\mathrm{Pb}$ isotopes in Antarctic ice will be required to study variations in $\mathrm{Pb}$ isotopic compositions during interglacials and to further investigate climate-related variations in $\mathrm{Pb}$ isotopes. The location of a drilling site in Antarctica with minimal isotopic interference from volcanism would also allow improved evaluation of Antarctic dust provenance by $\mathrm{Pb}$ isotopes.

\section{Acknowledgements}

This research was supported in Australia by the Australian Research Council (DP0345625) and the Antarctic Science Advisory Committee (\#1092,2334); In France by the Institut Universitaire de France, the Ministere de l'Environnement et de l'Amenagemont du Territoire, the Agence de l'Environnement et de la Martrise de l'Energie and the Institut National des Sciences de l'Univers; and in Italy by the Consorzio per l'Attuazione del Programma Nazionale delle Ricerche in Antartide, under projects on Environmental Contamination and Glaciology. FV acknowledges the FWO-Vlaanderen for the financial support under the form of the research projects G.0669.06 and G.0585.06. PV acknowledges the support of a European Union Marie Curie IIF Fellowship (MIF1-CT-2006-039529, TDICOSO) and an ANSTO travel stipend to attend INQUA2007, and would also like to thank G. Nanson and K. Fitzsimmons and all colleagues who participated in the "InnamINQUA" field trip associated with the INQUA2007 conference. EB is a Research Assistant of the Fund for Scientific Research - Flanders (FWO-Vlaanderen). We thank all Antarctic field personnel, G. Cozzi, F. Planchon, K. Latruwe, and L. Burn for laboratory support and helpful discussions. This work is a contribution to the European Project for Ice Coring in Antarctica (EPICA), a joint European Science Foundation/European Commission scientific programme, funded by the EU and by national contributions from Belgium, Denmark, France, Germany, Italy, the Netherlands, Norway, Sweden, Switzerland and the United Kingdom. The main logistic support was provided by IPEV and PNRA (at Dome C) and AWI (at Dronning Maud Land). This is EPICA publication no. 226.

\section{Appendix. Supplementary information}

Supplementary information related to this article can be found at doi: 10.1016/j.quascirev.2009.06.019.

\section{References}

Barreiro, B., 1983. Lead isotopic compositions of South Sandwich Island volcanic rocks and their bearing on magmagenesis in intra-oceanic island arcs. Geochim. Cosmochim. Acta 47, 817-822.

Bollhöfer, A.F., Rosman, K.J.R., 2000. Isotopic source signatures for atmospheric lead the Southern Hemisphere. Geochim. Cosmochim. Acta 64 (19), 3251-3262.

Bollhöfer, A.F., Honeybun, R., Rosman, K., Martin, P., 2006. The lead isotopic composition of dust in the vicinity of a uranium mine in northern Australia and its use for radiation dose assessment. Sci. Total Environ. 366 (2-3), 579-589.

Chow, T.J., Patterson, C.C., 1962. The occurrence and significance of lead isotopes in pelagic sediments. Geochim. Cosmochim. Acta 26, 263-308.

De Paolo, D.J., Manton, W.I., Grew, E.S., Halpern, M., 1982. Sm-Nd, Rb-Sr and $\mathrm{U}-\mathrm{Th}-\mathrm{Pb}$ systematics of granulite facies rocks from the Fyfe Hills, Enderby Land, Antarctica. Nature 298, 614-618.

Delmonte, B., Basile-Doelsch, I., Petit, J.-R., Maggi, V., Revel-Rolland, M., Michard, A., Jagoutz, E., Grousset, F.E., 2004. Comparing the EPICA and Vostok dust records 
during the last 220,000 years: stratigraphical correlation and provenance in glacial periods. Earth-Sci. Rev. 66, 63-87.

Delmonte, B., Petit, J.R., Basile-Doelsch, I., Jagoutz, E., Maggi, V., 2007. Late Quaternary Interglacials in East Antarctica from ice core dust records. In: Sirocko, F. Litt, T., Claussen, M. (Eds.), The Climate of Past Interglacials. Elsevier, Amsterdam.

Delmonte, B., Andersson, P.S., Hansson, M., Schöberg, H., Petit, J.R., Basile-Doelsch, I., Maggi, V., 2008. Aeolian dust in East Antarctica (EPICA-Dome C and Vostok): provenance during glacial ages over the last 800 kyr. Geophys. Res. Lett. 35 , L07703. doi:10.1029/2008GL033382.

EPICA community members, 2004. Eight glacial cycles from an Antarctic ice core Nature 429 (6992), 623-628.

Fischer, H., Fundel, F., Ruth, U., Twarloh, B., Wegner, A., Udisti, R., Becagli, S., Castellano, E., Morganti, A., Severi, M., Wolff, E., Littot, G., R̂thlisberger, R., Mulvaney, R., Hutterli, M.A., Kaufmann, P., Federer, U., Lambert, F., Bigler, M., Hansson, M., Jonsell, U., de Angelis, M., Boutron, C., Siggaard-Andersen, M.-L., Steffensen, J.P., Barbante, C., Gaspari, V., Gabrielli, P., Wagenbach, D., 2007. Reconstruction of millennial changes in dust emission, transport and regional sea ice coverage using the deep EPICA ice cores from the Atlantic and Indian Ocean sector of Antarctica. Earth Planet. Sci. Lett. 260 (1-2), 340-354.

Fitzsimmons, K.E., Rhodes, E.J., Magee, J.W., Barrows, T.T., 2007. The timing of linear dune activity in the Strzelecki and Tirari Deserts, Australia. Quatern. Sci. Rev. 26, 2598-2616.

Flegal, A.R., Maring, H., Niemeyer, S., 1993. Anthropogenic lead in Antarctic sea water. Nature 365 (6443), 242-244

Gabrielli, P., Varga, A., Barbante, C., Boutron, C.F., Cozzi, G., Gaspari, V., Planchon, F.A.M., Cairns, W., Hong, S., Ferrari, C.P., Capodaglio, G., 2004 Determination of Ir and Pt down to the sub-femtogram per gram level in polar ice by ICP-SFMS using preconcentration and a desolvation system. J. Anal. At. Spectrom. 19, 831-837.

Gabrielli, P., Barbante, C., Boutron, C.F., Cozzi, G., Gaspari, V., Planchon, F.A.M., Ferrari, C.P., Turetta, C., Hong, S., Cescon, P., 2005. Variations in atmospheric trace elements in Dome C (East Antarctica) ice over the last two climatic cycles. Atmos. Environ. 39, 6420-6429.

Gabrielli, P., Wegner, A., Petit, J.R., Delmonte, B., De Deckker, P., Gaspari, V. Fischer, H., Ruth, U., Kriews, M., Boutron, C.F., Cescon, P., Barbante, C., 2010. A major glacial-interglacial change in aeolian dust composition as inferred from rare earth elements in Antarctic ice. Quatern. Sci. Rev. 29, 265-273.

Gaiero, D.M., 2007. Dust provenance in Antarctic ice during glacial periods: from where in southern South America? Geophys. Res. Lett. 34, L17707. doi:10.1029/ 2007GL030520.

Glasby, P., Williams, M.A.J., McKirdy, D.M., Symonds, R., Chivas, A.R., 2007. Late Pleistocene environments in the Flinders Ranges, Australia: preliminary evidence from microfossils and stable isotopes. Quatern. Australasia 24 (2), $19-28$.

Grousset, F.E., Biscaye, P.E., 2005. Tracing dust sources and transport patterns using $\mathrm{Sr}$, Nd and $\mathrm{Pb}$ isotopes. Chem. Geol. 222, 149-167.

Hart, S.R., Blusztajn, J., LeMasurier, W.E., Rex, D.C., 1997. Hobbs Coast Cenozoic volcanism: implications for the West Antarctic rift system. Chem. Geol. 139, 223-248.

Hinkley, T.K., 2007. Lead (Pb) in old Antarctic ice: some from dust, some from other sources. Geophys. Res. Lett. 34, L08502. doi:10.1029/2006GL028736.

Hole, M.J., Kempton, P.D., Millar, I.L., 1993. Trace-element and isotopic characteristics of small-degree melts of the asthenosphere: evidence from the alkalic basalts of the Antarctic Peninsula Chem. Geol. 109, 51-68.

Hong, S., Kim, Y., Boutron, C.F., Ferrari, C.P., Petit, J.R., Barbante, C., Rosman, K.J.R., Lipenkov, V.Y., 2003. Climate-related variations in lead concentrations and sources in Vostok Antarctic ice from 65,000 to 240,000 years BP. Geophys. Res. Lett. 30 (22), 2138

Jouzel, J., Masson-Delmotte, V., Cattani, O., Dreyfus, G., Falourd, S., Hoffman, G.L. Minster, B., Nouet, J., Barnola, J.-M., Chappelaz, J., Fischer, H., Gallet, J.C., Johnsen, S., Leuenberger, M., Loulergue, L., Luethi, D., Oerter, H., Parrenin, F. Raisbeck, G., Raynaud, D., Schilt, A., Schwander, J., Selmo, E., Souchez, R., Spahni, R., Stauffer, B., Steffensen, J.P., Stenni, B., Stocker, T.F., Tison, J.L., Werner, M., Wolff, E.W., 2007. Orbital and millennial Antarctic climate variability over the past 800,000 years. Science 317, 793-796. doi:10.1126/science.1141038.

Kershaw, A.P., Nanson, G.C., 1993. The last full glacial cycle in the Australian region. Global Planet. Change 7, 1-9.

Lambert, F., Delmonte, B., Petit, J.R., Bigler, M., Kaufmann, P.R, Hutterli, M.A Stocker, T.F., Ruth, U., Steffensen, J.P., Maggi, V., 2008. Dust-climate couplings over the past 800,000 years from the EPICA Dome C ice core. Nature 452 (7187), $616-619$
Lanci, L., Delmonte, B., Maggi, V., Petit, J.R., Kent, D.V., 2008. Ice magnetization in the EPICA-Dome $C$ ice core: implication of dust sources during glacial and interglacial periods. J. Geophys. Res. 113. doi:10.1029/2007JD009678.

Li, F., Ginoux, P., Ramaswamy, V., 2008. Distribution, transport, and deposition of mineral dust in the Southern Ocean and Antarctica: contribution of major sources. J. Geophys. Res. 113. doi:10.1029/2007JD009190.

Mackie, D.S., Boyd, P.W., McTainsh, G.H., Tindale, N.W., Westberry, T.K., Hunter, K.A., 2008. Biogeochemistry of iron in Australian dust: from eolian uplift to marine uptake. Geochem. Geophys. Geosyst. 9 (3). doi:10.1029/2007GC001813.

Magee, J.W., Miller, G.H., Spooner, N.A., Questiaux, D., 2004. Continuous 150 k.y. monsoon record from Lake Eyre, Australia: insolation-forcing implications and unexpected Holocene failure. Geology 32 (10), 885-888.

Mahowald, N., Baker, A.R., Bergametti, G., Brooks, N., Duce, R.A., Jickells, T.D., Kubilay, N., Prospero, J.M., Tegen, I., 2005. Atmospheric global dust cycle and iron inputs to the ocean. Global Biogeochem. Cycles 19. doi:10.1029/2004GB002402.

Marx, S.K., Kamber, B.S., McGowan, H.A., 2005. Estimates of Australia dust flux into New Zealand: quantifying the eastern Australia dust plume pathway using trace element calibrated ${ }^{210} \mathrm{~Pb}$ as a monitor. Earth Planet. Sci. Lett. 239, 336-351.

Matsumoto, A., Hinkley, T.K., 2001. Trace metal suites in Antarctic pre-industrial ice are consistent with emissions from quiescent degassing of volcanoes worldwide. Earth Planet. Sci. Lett. 186, 33-43.

Nanson, G.C., Price, D.M., Jones, B.G., Maroulis, J.C., Coleman, M., Bowman, H., Cohen, T.J., Pietsch, T.J., Larsen, J.R., 2008. Alluvial evidence for major climate and flow regime changes during the middle and late Quaternary in eastern central Australia. Geomorphology 101, 109-129.

Parrenin, F., Barnola, J.M., Beer, J., Blunier, T., Castellano, E., Chappellaz, J., Dreyfus, G., Fischer, H., Fujita, S., Jouzel, J., Kawamura, K., Lemieux-Dudon, B., Loulergue, L., Masson-Delmotte, V., Narcisi, B., Petit, J.R., Raisbeck, G., Raynaud, D., Ruth, U., Schwander, J., Severi, M., Spahni, R., Steffensen, J.P., Svensson, A., Udisti, R., Waelbroeck, C., Wolff, E., 2007. The EDC3 chronology for the EPICA Dome C ice core. Clim. Past Discuss. 3 (2), 575-606.

Planchon, F.A.M., Van de Velde, K., Rosman, K.J.R., Wolff, E.W., Ferrari, C.P., Boutron, C.F., 2003. One hundred fifty-year record of lead isotopes in Antarctic snow from Coats Land. Geochim. Cosmochim. Acta 67 (4), 693-708.

Revel-Rolland, M., De Dekker, P., Delmonte, B., Hesse, P.P., Magee, J.W., BasileDoelsch, I., Grousset, F.E., Bosch, D., 2006. Eastern Australia: a possible source of dust in East Antarctica interglacial ice. Earth Planet. Sci. Lett. 249, 1-13.

Rosman, K.J.R., Chisholm, W., Boutron, C.F., Candelone, J.-P., Patterson, C.C., 1994. Anthropogenic lead isotopes in Antarctica. Geophys. Res. Lett. 21 (24), 2669-2672.

Rosman, KJ.R., Chisholm, W, Boutron, C.F., Hong, S, Edwards, R., Morgan, V., Sedwick, P.N., 1998. Lead isotopes and selected metals in ice from Law Dome, Antarctica. Ann. Glaciol. 27, 349-354.

Sims, K.W.W., Blichert-Toft, J., Kyle, P.R., Pichat, S., Gauthier, P.-J., Blusztajn, J., Kelly, P., Ball, L., Layne, G., 2008. A Sr, Nd, Hf, and Pb isotope perspective on the genesis and long-term evolution of alkaline magmas from Erebus volcano, Antarctica. J. Volcanol. Geotherm. Res. 177 (3), 606-618.

Sun, S.S., Hanson, G.H., 1975. Origin of Ross Island Basanitoids and limitations upon the heterogeneity of mantle sources for alkali basalts and naphelinites. Contrib. Mineral. Petrol. 52, 77-106.

Vallelonga, P., Van de Velde, K., Candelone, J.-P. Ly, C., Rosman, KJ.R., Boutron, C.F, Morgan, V.I., Mackey, D.J., 2002a. Recent advances in measurement of $\mathrm{Pb}$ isotopes in polar ice and snow at sub-picogram per gram concentrations using thermal ionisation mass spectrometry. Anal. Chim. Acta 453, 1-12.

Vallelonga, P., Van de Velde, K., Candelone, J.-P., Morgan, V.I., Boutron, C.F. Rosman, K.J.R., 2002b. The lead pollution history of Law Dome, Antarctica, from isotopic measurements on ice cores: 1500 AD to 1989 AD. Earth Planet. Sci. Lett. 204, 291-306.

Vallelonga, P., Gabrielli, P., Rosman, K.J.R., Barbante, C., Boutron, C.F., 2005. A 220 kyr record of $\mathrm{Pb}$ isotopes at Dome $\mathrm{C}$ Antarctica from analyses of the EPICA ice core. Geophys. Res. Lett. 32 (1), L01706.

Van de Velde, K., Vallelonga, P., Candelone, J.-P., Rosman, K.J.R., Gaspari, V., Cozzi, G., Barbante, C., Udisti, R., Cescon, P., Boutron, C.F., 2005. Pb isotope record over one century in snow from Victoria Land, Antarctica. Earth Planet. Sci. Lett. 232, 95-108.

Wedepohl, K.H., 1995. The composition of the continental crust. Geochim. Cosmochim. Acta 59 (7), 1217-1232.

White, W.M., Albarede, F., Telouk, P., 2000. High-precision analysis of $\mathrm{Pb}$ isotope ratios by multi-collector ICP-MS. Chem. Geol. 167, 257-270.

Wieser, M.E., Schwieters, J.B., 2005. The development of multiple collector mass spectrometry for isotope ratio measurements. Int. J. Mass Spectrom. 242 (2-3), 97-115. 